\title{
COLLAGEN DISEASE COMPLICATING MALIGNANCY
}

\author{
BY \\ JOHN LANSBURY \\ From the Department of Medicine, Temple University School of Medicine, Philadelphia, Pa.
}

(RECEIVED FOR PUBLICATION AUGUST 28, 1953)

My purpose in submitting the following six case reports is to call attention to what is, I believe, a significant and little recognized relationship between neoplastic disease and the so-called "collagen" group of rheumatic or connective tissue diseases. The first case, observed in 1946, was so striking that a careful watch was kept for similar cases. The vigil was rewarded over a period of 7 years by another five cases. The case reports have been reduced to a bare minimum-summaries of pertinent positive information-since the object in view is to illustrate the co-existence of two obvious diseases in each patient rather than to prove the correctness of the diagnosis by furnishing a multiplicity of detailed evidence.

Case 1. Male, aged 44, a blind musician, was first seen in the Temple University Arthritis Clinic in June, 1946.

History.-He had had painful joints of 4 months' duration. The arthritis had a rather sudden onset and spread rapidly, so that in a few weeks the shoulders, elbows, wrists, metacarpophalangeal and proximal interphalangeal joints, and knees were involved.

Examination.-Physical examination disclosed the typical findings of rheumatoid arthritis with fusiform swelling, tenderness, limitation of motion, muscle atrophy, and weakness. Other findings included a harsh systolic murmur heard over the whole praecordium, congenital amblyopia, poor nutrition, a chronic cough, and seborrhoeic dermatitis. The erythrocyte sedimentation rate (Cutler) was rapid, the electrocardiogram (by Dr. Hugo Roesler) indicated a primary myocarditis and possible pericarditis with no features suggesting rheumatic fever.

Further Symptoms.-About a month later the patient complained of radicular pain arising from a lumbar segment and of dysphagia. Subsequent studies revealed a carcinoma of the oesophagus with metastases to the lumbar spine and a supraclavicular lymph node. The arthritis, which had been treated by gold therapy slowly improved, but the patient died 1 year from the onset of his arthritis of malnutrition and generalized metastases
Autopsy.-A Grade II squamous cell carcinoma was found with widespread metastases involving the pericardium, pleura, peritoneum, and adrenal. The heart showed advanced myocardosis, thickened and calcified aortic leaflets, and a fibrinous pericarditis.

Comment.-The neoplasm almost certainly preceded the arthritis. The diagnosis of rheumatoid arthritis seems justified from a clinical point of view rather than a diagnosis of rheumatic fever. The rheumatic process appears to be an incident occurring during a rapidly evolving malignant process even though it was at first the outstanding feature of the case.

Case 2. Married female, aged 52, began having symptoms of intestinal obstruction in January, 1946.

History.-A Krunkenberg tumour involving the large bowel with metastases to both ovaries was found 6 months later and a partial resection of the colon and a bilateral oophorectomy were performed. I saw the patient at this time and no articular symptoms or signs were noted. Some months later, the patient developed generalized muscle pain, and, when observed 1 year following her operation, was found to be suffering from a low grade arthritis of the right shoulder, both elbows and knees, and small joints of the hands.

Examination.-Physical examination revealed minimal tenderness and swelling of the affected joints and limitation of motion of the right shoulder. There was a mild chronic ethmoiditis, but otherwise no evidence for focal infection. The rest of the physical examination was not remarkable. The erythrocyte sedimentation rate was $15 \mathrm{~mm} .{ }^{\prime} 1 \mathrm{hr}$ (Cutler).

Therapy.-She was treated with a programme of extra rest, salicylates, testosterone, and local shrinkage of the nasal mucous membranes. In the following 3 months the articular symptoms improved, but the muscle stiffness persisted. She died elsewhere in August, 1947.

Autopsy (performed locally).-Widespread peritoneal metastases were revealed.

Comment.-This case illustrates the appearance of a low grade rheumatoid arthritis occurring during the course of a fatal malignancy. It is possible that the 
ethmoiditis and the surgical removal of the ovaries were also factors in precipitating the rheumatic episode.

Case 3. Male, aged 69, suddenly developed, in October, 1949, an erythematous rash on all four extremities, face, neck, and upper thorax.

History.-Generalized stiffness, pain, weakness, and swelling of the musculature followed in a few days. The oedematous features of the illness receded, but the erythematous skin rash persisted and the muscle symptoms became more pronounced. An eosinophilia was noted at this time. The patient was seen by us 3 months after the onset of these symptoms, at which time he had difficulty in swallowing which he related to the upper oesophagus.

Examination.-Physical examination showed an irregular fever up to $101^{\circ} \mathrm{F}$., generalized muscle tenderness, multiple doughy indurations involving the skin and muscles, limitation of motion of the shoulders, elbows, hands, and knees, and a patchy erythematous rash resembling in some respects that of disseminated lupus erythematosus. Oesophagoscopy revealed only moderate oedema and narrowing of the upper oesophagus. Pertinent laboratory studies revealed a persistent pyuria and microscopic haematuria. Urological studies disclosed a lesion of the right kidney as the source of the abnormal urinary findings.

Diagnosis.-Dermatomyositis.

Therapy.-The patient was treated with potassium para-aminobenzoate, but he responded poorly and succumbed in April, 1950, death being attributed to dermatomyositis.

Autopsy.-A papillary carcinoma of the right renal pelvis was found with metastases to the peri-aortic lymph nodes, a small neurilemmona of the stomach, ulceration of the pharynx, polymyositis of the skeletal musculature, and terminal broncho-pneumonia. The cause of death was dermatomyositis.

Comment.-Although the main clinical feature of this case was dermatomyositis, which ran a 6 months' course and was the immediate cause of death, it is certain that a carcinoma of the right kidney existed 8 weeks after the onset of the illness, and was, in all probability, present well before the onset of the dermatomyositis.

Case 4. Male, aged 36, was admitted to Temple University Hospital in May, 1952, because of infertility.

History.- He had suffered from recurrent episodes of left testicular pain for about 1 year, and was of an allergic diathesis, having suffered periodically from asthma and migraine; 6 weeks before admission he had had an episode of pain and stiffness of the shoulders and hands which persisted and slowly became worse.

Examination.-Physical examination revealed a pale eunuchoid male; there was bilateral limitation of shoulder motion, and swelling, tenderness, and limitation of motion of wrists and fingers. The left testis was moderately enlarged, firm, warm, and tender. The right testis was absent.
Diagnosis.-A clinical diagnosis of atypical rheumatoid $\stackrel{\mathbb{D}}{=}$ arthritis was made and studies were begun to exclude $\overline{3}$ disseminated lupus erythematosus and peri-arteritis $\frac{\square}{\text { n. }}$ nodosa.

Laboratory Studies. $-X$ ray of the chest disclosed a $\overrightarrow{\bar{F}}$ large mass in the left lower lobe, which was at first believed to be a metastatic malignancy. Biopsy of the left $\frac{\bar{\sigma}}{\sigma}$ testis disclosed the histological findings of a malignant $\overline{\bar{c}}$

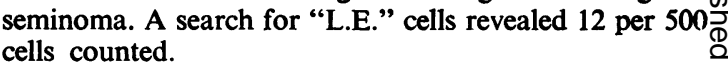

Therapy.-The patient underwent an orchidectomy and was treated by $x$ irradiation therapy and nitrogen $\overrightarrow{0}$ mustard. Two months later all signs and symptoms of arthritis had disappeared, and when observed 9 months $\vec{\omega}$ later the patient was gaining in strength and in weight. Subsequent $x$ rays of the chest showed no progress of the mass, which is now believed to be of a benign type,
unrelated to the malignant seminoma.

Comment.-The diagnosis was malignant seminoma of $\frac{\vec{c}}{\omega}$ the left testis associated with disseminated lupus erythe-으 matosus with articular manifestations. Unquestionably응 the neoplasm preceded the "arthritis" in this case.

Case 5. Male,* aged 63, a merchant, was well, except for controlled diabetes, until April, 1953.

History.-He began to have increasing pain in the $\frac{D}{3}$ right knee with subsequent involvement of the left knee⿻्巳 and both elbows, and later diffuse pain in the long bones? and muscles, most marked in the low back and thigis. 6 When seen by us in August, 1953, he had lost $30 \mathrm{lb}$. Inw weight and his diabetes was poorly controlled.

Examination.-Physical examination revealed a supraclavicular lymph node on the right, myopia, tracheal deviation to the left, a firm, nodular, moderatelyenlarged liver, swelling and fluid in the right knee, $\frac{\mathrm{O}}{\mathbb{Q}}$ tenderness of both elbows, and minimal flexion deform-은 ities of the right elbow and knee with pain on forced $\overrightarrow{\vec{O}}$ extension. The long bones were tender. There was muscle 3 wasting of the right thigh and the interossei. The right patellar reflex and both Achilles reflexes were absent.

Laboratory Findings.-Diabetes, which was quickly brought under control, a large mediastinal mass (probably a bronchogenic carcinoma), which was observed to $\frac{\sigma}{3}$ enlarge rapidly on serial roentgen studies, and a metastatic adenocarcinoma (revealed by a lymph-nodeo biopsy). Alkaline phosphatase elevated (11 Bodansky units), erythrocyte sedimentation rate rapid, serumo albumin decreased, cerebrospinal fluid normal. $X$ rays of the spine, knees, and long bones showed only moderate osteoporosis and minimal degenerative changes in keeping with the patient's age.

Further Developments.-During his hospital stay there $N$ has been a steady decline in his general status. The arthritis became more pronounced. Fluid was aspirated $\omega$ several times from the right knee and compound $F$ instilled with good symptomatic relief.

Comment.-The "arthritis" in this case is indis-市

* This case was seen in consultation with Dr. H. Baier. 
tinguishable from rheumatoid arthritis. The malignancy almost certainly preceded it, although it gave no local symptoms. Much of the diffuse bone and muscle pain could be explained either on the basis of diabetic neuronitis or as variant of the Bamberger-Marie syndrome. No $x$-ray evidence of bone metastases was found.

Case 6. Male, aged 57, suffered from a Grade 3 squamous cell carcinoma of the epiglottis and larynx, which was irradiated and excised in October, 1952.

History.-Chest $x$ ray showed a nodule in the left lower lobe, which increased in size and was biopsied in November, 1952, yielding a histological diagnosis of squamous cell carcinoma, and is presumed to be metastatic from the laryngeal lesion.

In March, 1953, the patient developed arthritis of the left shoulder and by July both knees and ankles were involved, with pain, swelling, local heat, and fluid accumulation.

In June, 1953, the patient had an episode of phlebothrombosis of one leg followed by haemoptysis which was diagnosed as a pulmonary embolism. At this timeclubbing of all the fingers began and rapidly evolved.

Examination.-In October, 1953, the erythrocyte sedimentation rate was 36 (Wintrobe), aspirated fluid from the knee showed only 157 white blood cells and the glacial acetic acid test was indeterminate. Culture of the joint fluid was negative. The albumin/globulin ratio and alkaline phosphatase were normal. A search for "L.E." cells revealed 3 per 500 counted.

Comment.-We have here a respiratory tract neoplasm of at least one year's duration (squamous cell carcinoma) complicated by a slowly progressive large-joint arthritis clinically resembling rheumatoid arthritis. The presence of "L.E." cells raises the question of co-existing lupus erythematosus disseminatus as the explanation of the "arthritis". The clubbing would ordinarily be classed as the Bamberger-Marie Syndrome.

\section{Discussion}

At this point, the reader will probably suggest that, since both neoplastic disease and the various "collagen" or connective tissue disorders are quite prevalent, their co-existence in six patients could easily be attributed to chance. The chances to be considered, however, are not those of the coincidence of these two types of disease at any time in a lifespan of let us say 70 years, but rather the chance of a rheumatic disease arising spontaneously in the first 6 months or 1 year of a malignant neoplastic invasion. Even with the "chance" explanation thus considerably reduced, I would prefer to offer these cases as illustrative of the co-existence of neoplasm and collagen disease rather than as proof of a causal relation between the two.

However, considerable supporting evidence for such a causal relation is available. One may mention first the subacute type of arthritis not uncommonly found as the presenting symptoms of leukaemia (a type of neoplastic disease) in infants, children, and adolescents.

Furthermore, the association of dermatomyositis with neoplastic disease has been reported in a total of 29 cases (Cottel, 1952; Brunner and Lobraico, 1951; Curtis and others, 1952). Analysis of these reports shows the majority to be cases of carcinoma arising from ovary, stomach, breast, oesophagus, gall-bladder, cervix vagina, rectum, and parotid gland. Other neoplastic processes were retro-peritoneal and endothelial sarcoma of bone, multiple myeloma, Hodgkin's disease, and reticulo-endothelial malignancy, all of which were associated with dermatomyositis.

This suggests that the dermatomyositis was precipitated by some factor common to neoplasia in general. In ten of the above cases the dermatomyositis improved with removal of the tumour and in some instances recurred with regrowth of the tumour.

A recent report by Polley and others (1952) of articular reactions in eighteen of 24 patients suffering from localized fibrous mesothelioma of the pleura states that, while the majority of the articular lesions were attributed to pulmonary osteo-arthropathy, in four instances the findings were similar to those encountered in rheumatoid arthritis. Pulmonary osteoarthropathy and the other articular manifestations subsided after removal of the tumour and recurred when the tumour recurred in three out of the four cases.

Hansen (1952) reports four cases of generalized arthritis with swelling, tenderness, pain, and limited motion of the joints associated with carcinoma of the lung.* In each case the arthritis was the presenting symptom and the lung lesion was discovered on routine chest $x$ ray. After resection of the squamous cell carcinoma in three of the cases, the arthritis disappeared promptly and permanently. A subsequent review of one hundred cases of bronchogenic carcinoma by the same author revealed an incidence of 12 per cent. of cases with arthralgia as a presenting symptom.

From the foregoing, I believe we may conclude that there is indisputable evidence for the appearance of certain members of the group of "collagen" diseases during the evolution of a wide range of otherwise unrelated malignant neoplasms. The reversal of the collagen disease following successful removal of the tumours is strong proof that some phase of malignancy bears a causal relationship to the collagen disease. Three cases of arthritis indistinguishable from rheumatoid arthritis, one

* This is not to be confused with pulmonary osteoarthropathy. 
case of dermatomyositis, and two cases of presumptive disseminated lupus erythematosus have been cited here. There is suggestive evidence for an allergic diathesis in four of these cases, but it is impossible to know the significance, if any, of this factor.

As to the nature of the relationship one can only speculate. This phenomenon is not due to any one specific type of neoplasm but rather to some unknown factor common to neoplasms in general. Since one feature common to all malignancies is that of invasion, and since the collagenoses can be reversed by removal of the tumour, it seems not unlikely that this phenomenon is related to some factor facilitating the invasion of malignant cells. It may not be too fanciful to assume that the factor in question is a hyaluronidase-like substance which, by entering the general circulation, may interfere with the hyaluronate components of connective tissues and their attending enzymes and co-enzymes. Less likely would be the hypothesis that a malignancy acts as a stressor or as an antigen, or that infection within the neoplasm is the factor. Although this observation of a relationship between malignancy and the collagen diseases cannot at present be fitted into our concepts of the pathogenesis of the collagen diseases, there is little doubt that, if it were understood, it would provide an important step toward understanding the cause of the rheumatic diseases.

From a practical, clinical point of view, the above observations lead to the formulation of the following rule:

When dermatomyositis or collagen disease occurs in middle age without a recognizable precipitating factor, a careful search for malignancy is mandatory.

\section{Summary}

Over a period of 7 years, six cases of "collagen disease" (rheumatoid arthritis, dermatomyositis, and disseminated lupus erythematosus) have been seen, which arose in patients suffering from the following types of malignancy:

Carcinoma of the oesophagus,

Krukenberg tumour of the colon,

Carcinoma of the kidney,

Malignant seminoma of the testes,

Metastatic adenocarcinoma and bronchogenic carcinoma,

Carcinoma of the lung.

In all instances the neoplasm preceded the collagen disease, although the presenting symptom in four of the six cases was "arthritis" and the malignancy was at first unsuspected. Four patients were of an allergic diathesis although their allergies were $\frac{\widehat{\Phi}}{\Xi}$
clinically unimportant.

A review of the literature discloses reports of $\frac{\square}{\omega}$. numerous instances of co-existence of malignancy? and collagen disease, the most frequent being $\vec{s}$ dermatomyositis, and, less frequently, a form of arthritis clinically indistinguishable from rheumatoid $\frac{C}{O}$ arthritis. This co-existence is believed not to be due $\frac{\overline{\bar{N}}}{\bar{D}}$. to chance, since in many instances removal of the $\widetilde{\Phi}$ neoplasm was followed by disappearance of the arthritis or dermatomyositis.

The mechanism of this relationship is unknown, $\vec{O}$

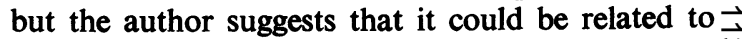
some hyaluronidase-like factor secreted by malignant $\omega$ cells which assists their invasion.

These observations indicate that when dermato-? myositis or arthritis, or any one of the collagen $\vec{N}$ diseases, occurs in older patients without preceding stress, a careful search for hidden malignancy is $\omega$ mandatory.

\section{REFERENCES}

Brunner, M. J., and Lobraico, R. V. (1951). Ann. intern. Med., $\rightarrow$

Cottel, C. E. (1952) Amer. J. med. Sci., 224, 160.

Curtis, A. C., Blaylock, H. C., and Harrell, E. R., Jr. (1952). J. Amer. med. Ass., 150, 844.

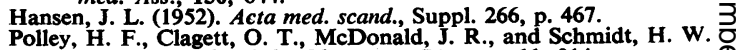
(1952). Annals of the Rheumatic Diseases, 11, 314.

\section{Summario*}

Durante un periodo de 7 annos le autor ha collecte. 6 casos del dyscollagenoses (arthritis rheumatoide, dermatomyositis, lupus erythematose disseminate) patientes suffrente del sequente typos de malignitate:

Carcinoma del esophago,

Tumor Krukenberg del colon,

Carcinoma renal,

Seminoma maligne del testes,

Metastatic carcinoma e carcinoma bronchogenic.

Carcinoma del pulmon.

In omne casos le neoplasmo precedeva le morbo de collageno ben que le symptoma saliente in 4 ex le 6 casos era "arthritis" e initialmente nulle malignitate era suspectate. Quatro del patientes habeva un diathese allergic mais lor symptomas allergic era clinicamente non importante.

Un revista del literatura revela reportos de numerose exemplos del co-existentia de malignitates con morbos de collageno, le plus frequentemente dermatomyositis, $\frac{}{工}$ minus frequentemente un forma de arthritis clinicamente $D$ indistinguibile ab arthritis rheumatoide. Iste co-existentia nos crede, non es accidental, proque in plure casos le $N$ excision del neoplasma era sequite per le disparition 0 del arthritis e dermatomyositis.

* This summary is presented by the author in the international $\mathrm{W}$ vocabulary "Interlingua", which has recently been completed and is $\sigma$ being sponsored by Science Service as a translation language for summaries and abstracts. The usual French and Spanish Summaries 0 are given as well for comparison. The Editors of the Annals of the Rheumatic Diseases will be glad to receive comments from subscribers $\mathbb{D}$ of all nations on the intelligibility and usefulness of this vocabulary as an instrument in the international communication of scientific ? statements. 
Le mechanismo per le qual malignitates pote precipitar un morbo de collageno es incognite, mais le autor postula que il poterea esser relationate a alicun factor hyaluronidasoide que es secretate per le cellulas maligne pro adjuvar lor invasion.

Iste observationes indica que quando dermatomyositis, arthritis o alicun del morbos de collageno, occurre in plus vetere patientes sin traumatismo precedente, alora un cerca diligente pro un celate malignitate es mandatari.

\section{Maladie collagène compliquant la malignité}

\section{RÉSUMÉ}

Au cours d'une période de 7 ans l'auteur a recueilli 6 cas de maladie collagène (arthrite rhumatismale, dermatomyosite et lupus érythémateux disséminé) chez des sujets atteints d'une des affections suivantes:

Carcinome de l'oesophage,

Tumeur de Krukenberg du colon,

Carcinome du rein,

Séminome maligne,

Adénocarcinome métastatique et carcinome bronchogène,

Carcinome du poumon.

Dans tous les cas le néoplasme avait précédé la maladie collagène, bien que dans quatre cas sur six ce fut une "arthrite" qui attira l'attention alors que la malignité ne fut guère soupçonnée. Ces quatre malades présentèrent une diathèse allergique mais leurs allergies n'eurent pas d'importance clinique.

Une revue de la littérature revèle des observations de nombreux cas où la malignité et la maladie collagène coëxistaient; le plus souvent il s'agissait d'une dermatomyosite, moins souvent d'une arthrite indiscernable cliniquement d'une arthrite rhumatismale. On croit que cette coexistence n'est pas fortuite car dans beaucoup de cas l'arthrite ou la dermatomyosite disparaissait après l'ablation de la tumeur.

On ne conna $t$ pas le mécanisme de ce rapport, mais l'auteur admet la possibilité de l'intervention d'un facteur dans le genre de hyaluronidase, secrété par les cellules malignes pour favoriser leur invasion.

Ces observations indiquent que chaque fois qu'une dermatomyosite, une arthrite ou toute autre maladie collagène survient chez une personne âgée sans être précédée par un facteur précipitant déterminable, la recherche soigneuse de la malignité s'impose.

\section{Enfermedad colagena complicando la malignidad}

$$
\text { Sumario }
$$

Durante un período de 7 años el autor ha recogido 6 casos de enfermedad colagena (artritis reumatoide, dermatomiositis y lupus eritematoso diseminado) en pacientes con una de las afecciones siguientes:

Carcinoma del esófago,

Tumor de Krukenberg del colon,

Carcinoma del riñon,

-seminoma maligno,

Adenocarcinoma metastásico y carcinoma broncógeno,

Carcinoma del pulmón.

En todos los casos el neoplasma había precedido la enfermedad colagena, aunque en cuatro de los cinco casos una "artritis" fué la primera manifestación sin que al principio se sospechara la malignidad. Los cuatro enfermos presentaron una diatesis alérgica pero estas alergías no tuvieron importancia clínica.

Una revista de la literatura revela relatos de numerosos casos de coexistencia de la malignidad y de la enfermedad colagena, tratándose más frecuentemente de una dermatomiositis y con menos frecuencia de una artritis indistinguible clínicamente de una artritis reumatoide. Se cree que esta coexistencia no es accidental, ya que en muchos casos la artritis o la dermatomiositis desaparecía al extirpar el tumor.

No se conoce el mecanismo de esta relación, pero el autor sugiere la posibilidad de la intervención de un factor del tipo de hialuronidase secretado por las células malignas para favorecer su invasión.

Estas observaciones indican que siempre que una dermatomiositis, una artritis o cualquier otra enfermedad colagena ocurre en una persona de edad avanzada sin que un factor precipitante determinable la precediese, la búsqueda cuidadosa de la malignidad es perentoria. 